DOI: 10.52363/passa-2021.1-2

UDC: 351.86

Babenko Volodymyr, PhD candidate, Educational, Scientific and Production Center National university of civil defence of Ukraine, Kharkiv.

ORCID: 0000-0001-8973-4032

\title{
GENESIS OF FORMATION AND DEVELOPMENT OF ORGANIZATIONAL AND LEGAL MECHANISM OF PUBLIC MANAGEMENT OF SOCIAL CONFLICTS IN UKRAINE
}

The article examines the genesis of formation and development of organizational and legal mechanism of public management of social conflicts in Ukraine by conducting a content analysis. Within its limits, in particular, the National Security Strategies of Ukraine were studied from the standpoint of the state of determination of social conflicts in them.

Key words: organizational and legal mechanism of public administration, social conflicts, crisis, national security strategy of Ukraine.

Problem setting. At present social conflicts in Ukraine have become large-scale due to the constant change in the functioning of the organizational and legal mechanism of public management of social conflicts in Ukraine. This leads to the need to change both the vector of its development, as well as the improvement and updating of the regulatory framework of the country.

Analysis of the recent research activities and publications. Problematic issues that arise in the field of conflicts, in particular social ones, took centre stage during the scientific research of such domestic scientists: A. Bandurka, S. Belaya, O. Vasylieva, N. Didenko, S. Dombrovska, T. Karlova, O. Krutiy, O. Kryukov, R. Lukishi, A. PomazyPonomarenko, V. Sadkov, V. Stepanov and others. The works of foreign scientists (M. 
Weber, N. Wiener, R. Darendorf, K. Deutsch, L. Kozer, K. Levin, N. Luhmann, R. Merton, T. Parsons, J. Habermas, K. Jaspers etc.) made a significant contribution to the solution of socio-philosophical, methodological and general theoretical problems of social conflict.

Conclusion of the research. To determine the directions and features of the formation of the organizational and legal mechanism of public management of social conflicts in Ukraine, outlining the prospects for its development.

The paper main body. For the most part social conflicts in Ukraine are seen as a negative phenomenon and the most important goal of the state has been to resolve them. However, for some reason no one considers social conflict as an opportunity to improve the organizational and legal mechanism of public management of social conflicts in the direction of:

- updating of existing state programmes and development strategies of Ukraine; - improvement of the regulatory framework in the field of regional development; - simplification of the procedure for providing services to the people, expanding the range of services needed to address non-standard or new problems that lead to social conflicts, which can escalate into crises due to mismanagement or indifference on the part of the state to them.

Given this, social conflict is not always negative. On the contrary, social conflict should act as a catalyst for improvement and the introduction of new positive changes for the country. Social conflicts should initiate the introduction of innovations, detailed consideration of the redistribution of resources (resources used to resolve existing social conflicts are no longer available for use in other areas for state development).

At the same time, social conflict can harm the state and its interests. Strictly speaking, it not only increases tensions, dissatisfaction of the population and increases its distrust of the government, but also reduces the productivity of new resources, harms relations both within the country and international relations with other countries, strengthens resistance to beneficial change in the country and generates corruption, 
lobbying for certain groups of people, waste and misallocation of resources involved in resolving social conflict.

It is worth noting that the organizational and legal mechanism of public management of social conflicts in Ukraine is based primarily on the application of the legal framework of Ukraine, which in turn is being constantly updated and changed in order to remain relevant and meet today's challenges. Various programmes and strategies of the country's development are used for modern and sustainable development of the state.

Social conflicts in Ukraine affect the security of society and citizens. Therefore prevention, improvement and resolution of social conflicts in Ukraine are the areas of national security. Let us analyse the previously adopted and current national security strategies of Ukraine in terms of their effectiveness in the organizational and legal mechanism of public management of social conflicts in Ukraine, as well as compare strategies and draw conclusions concerning their improvement.

According to the Decree of the President of Ukraine No. 105/2007 "On the National Security Strategy of Ukraine as of February 12, 2007" [1] the main purpose of providing such security is to increase its level, which would guarantee Ukraine's progressive development, competitiveness, human rights and civil liberties, further strengthening of international positions and authority of Ukrainian state in the modern world. That is, the country's development is based primarily on foreign policy, and conflicts are seen only as external, primarily in Transnistria. From the point of view of the adopted National Security Strategy of Ukraine, there were no internal conflicts and risks of their occurrence in Ukraine. However the paragraph 2.1 of the analysed National Security Strategy of Ukraine identifies the risks for Ukrainian society due to cultural and historical differences of certain regions of Ukraine and speculation on this issue by some political groups. In our opinion, this caused a social conflict and escalated into a conflict in Eastern Ukraine.

Let us consider the example of the Decree of the President of Ukraine No. 287/2015 on the decision of the National Security and Defence Council of Ukraine as of May 6, 2015 "On the National Security Strategy of Ukraine" [2] and the Decree of the President 
of Ukraine No. 392/2020 on the decision of the National Security and Defence Council of Ukraine as of September 14, 2020 "On the National Security Strategy of Ukraine" [3]concerning the direction in which Ukraine has developed in relation to resolving social conflicts. The National Security Strategy of Ukraine was adopted in 2015 and was primarily aimed at minimizing threats to state sovereignty and creating conditions for restoring the territorial integrity of Ukraine within the internationally recognized state border of Ukraine, and only then to guarantee a peaceful future for Ukraine as a sovereign, independent, democratic, social, rule-of-law state and the establishment of human and civil rights and liberties, ensuring a new quality of economic, social and humanitarian development, as well as the integration of Ukraine into the European Union and the formation of conditions for NATO membership [p. 2.2]. Thus, the changes in legal documents are aimed at the foreign policy of preserving the borders of the state, protection of sovereignty, social, economic and humanitarian development, as well as the preservation of human rights and freedoms.

The analysis of the National Security Strategy of Ukraine (adopted in 2020) allows us to state that its key thesis is "Human security - security of the country". The priority within this strategy is the person, his/her life and health, honour and dignity, inviolability and security. Human is the highest social value in Ukraine (according to the norms of the Constitution of Ukraine), as well as the main goal of the state policy of national security [sub-item 1, item 1. 2]. Secondly, the state must protect citizens and society [sub-item 2,item 1.2], and thirdly — the sovereignty and territorial integrity of Ukraine within its internationally recognized state border [sub-item 3,item 1.2].

Comparing the directions of state development in 2015 and 2020, we can note the obvious change in the focus of state development and the change of priority from foreign policy to the citizens of the country (as in modern developed European countries).

From the point of view of the development of the organizational and legal mechanism of public management of social conflicts in Ukraine, the National Security Strategy of Ukraine (since 2015) mentions conflict resolution only in the main directions of state national security policy of Ukraine in the context of national security in foreign 
policy, international law and a just settlement of conflicts [sub-item 4.8,item 4.2]. Thus, within the period from 2015 to 2020 the organizational and legal mechanism of public management of social conflicts in Ukraine was considered only from the standpoint of compliance with international norms and did not develop in terms of changes in legal documents in Ukraine.

Within the period from 2020 (with the adoption of the National Security Strategy of Ukraine) the organizational and legal mechanism of public management of social conflicts in Ukraine has not developed in a substantial way. However, the settlement of conflicts is considered not only from the point of view of national security in the foreign policy area, but also from the point of view of internal conflicts [sub-item20, item 45.2].

Considering in detail the National Security Strategy of Ukraine (from 2020), we can note that there are no changes in the direction of development of the state, which does not correspond to the slogan "Human security - national security". Internal social conflicts in Ukraine are not considered a danger to citizens, therefore there are no ways to develop the legal framework of the country in this direction and as a result there is no development of organizational and legal mechanism of public management of social conflicts in Ukraine. As before, people are left alone with their problems and existing social conflicts, which lead to lower living standards, economic decline, increased unemployment and corruption (Table 1).

Table 1

Content analysis of National Security Strategies of Ukraine from the standpoint of defining social conflicts.

\begin{tabular}{|c|c|c|c|c|}
\hline \multirow{2}{*}{$\begin{array}{c}\mathrm{N} \\
\mathrm{s} / \mathrm{n}\end{array}$} & \multicolumn{3}{|c|}{ The National Security Strategy of Ukraine was adopted in } & \multirow{2}{*}{$\begin{array}{l}\text { Proposals to improve } \\
\text { Ukraine's national } \\
\text { security strategies }\end{array}$} \\
\hline & $2007[1]$ & $2015[2]$ & 2020 [3] & \\
\hline 1. & \multicolumn{4}{|c|}{ Priorities } \\
\hline & $\begin{array}{l}\text { The strategy defines } \\
\text { the principles, } \\
\text { priority goals, } \\
\text { objectives and } \\
\text { mechanisms to } \\
\text { ensure the vital } \\
\text { interests of the } \\
\text { individual, society }\end{array}$ & $\begin{array}{l}\text { Ukraine's national } \\
\text { security policy is } \\
\text { based on respect for } \\
\text { the norms and } \\
\text { principles of } \\
\text { international law. } \\
\text { Ukraine will defend } \\
\text { its fundamental }\end{array}$ & $\begin{array}{l}\text { Upholding } \\
\text { independence and } \\
\text { state sovereignty. } \\
\text { Restoration of } \\
\text { territorial integrity } \\
\text { within the } \\
\text { internationally } \\
\text { recognized state }\end{array}$ & $\begin{array}{l}\text { Put people and their } \\
\text { safety first. In second } \\
\text { place is the rapid } \\
\text { resolution of identified } \\
\text { social conflicts. }\end{array}$ \\
\hline
\end{tabular}




\begin{tabular}{|c|c|c|c|c|}
\hline \multirow{2}{*}{$\begin{array}{c}\mathrm{N} \\
\mathrm{s} / \mathrm{n}\end{array}$} & \multicolumn{3}{|c|}{ The National Security Strategy of Ukraine was adopted in } & \multirow{2}{*}{$\begin{array}{l}\text { Proposals to improve } \\
\text { Ukraine's national } \\
\text { security strategies }\end{array}$} \\
\hline & $2007[1]$ & $2015[2]$ & $2020[3]$ & \\
\hline & $\begin{array}{l}\text { and the state from } \\
\text { external and internal } \\
\text { threats. }\end{array}$ & $\begin{array}{l}\text { values, defined by } \\
\text { the Constitution and } \\
\text { laws of Ukraine - } \\
\text { independence, } \\
\text { territorial integrity } \\
\text { and sovereignty, } \\
\text { dignity, democracy, } \\
\text { man, his rights and } \\
\text { freedoms, rule of } \\
\text { law, welfare, peace } \\
\text { and security. Their } \\
\text { protection will be } \\
\text { provided by the } \\
\text { effective Armed } \\
\text { Forces of Ukraine, } \\
\text { other military } \\
\text { formations formed in } \\
\text { accordance with the } \\
\text { laws of Ukraine, } \\
\text { intelligence, } \\
\text { counterintelligence } \\
\text { and law enforcement } \\
\text { agencies of the state, } \\
\text { the dynamic } \\
\text { development of } \\
\text { Ukraine's economy. }\end{array}$ & $\begin{array}{l}\text { border of Ukraine. } \\
\text { Social development, } \\
\text { first of all } \\
\text { development of } \\
\text { human capital. } \\
\text { Protection of the } \\
\text { rights, freedoms and } \\
\text { legitimate interests of } \\
\text { the citizens of } \\
\text { Ukraine. European } \\
\text { and Euro-Atlantic } \\
\text { integration. }\end{array}$ & \\
\hline 2. & \multicolumn{4}{|c|}{ Objectives } \\
\hline & $\begin{array}{l}\text { 1. Achieving } \\
\text { national unity and } \\
\text { consolidation of } \\
\text { society by } \\
\text { overcoming both } \\
\text { objective and } \\
\text { artificial } \\
\text { contradictions of } \\
\text { socio-cultural, } \\
\text { confessional, ethnic, } \\
\text { linguistic, } \\
\text { interregional and } \\
\text { regional nature on } \\
\text { the basis of } \\
\text { unconditional } \\
\text { observance of } \\
\text { constitutional } \\
\text { guarantees of human } \\
\text { and civil rights and } \\
\text { freedoms. } 2 .\end{array}$ & $\begin{array}{l}\text { 1. Minimization of } \\
\text { threats to state } \\
\text { sovereignty and } \\
\text { creation of } \\
\text { conditions for } \\
\text { restoration of } \\
\text { territorial integrity of } \\
\text { Ukraine within the } \\
\text { internationally } \\
\text { recognized state } \\
\text { border of Ukraine, } \\
\text { guarantee of } \\
\text { peaceful future of } \\
\text { Ukraine as sovereign } \\
\text { and independent, } \\
\text { democratic, social, } \\
\text { legal state. } 2 \text {. } \\
\text { Establishing human } \\
\text { and civil rights and } \\
\text { freedoms, ensuring a }\end{array}$ & $\begin{array}{l}\text { 1. Upholding } \\
\text { independence and } \\
\text { state sovereignty. } 2 . \\
\text { Restoration of } \\
\text { territorial integrity } \\
\text { within the } \\
\text { internationally } \\
\text { recognized state } \\
\text { border of Ukraine. } 3 \text {. } \\
\text { Social development, } \\
\text { especially the } \\
\text { development of } \\
\text { human capital. } 4 . \\
\text { Protection of the } \\
\text { rights, freedoms and } \\
\text { legitimate interests } \\
\text { of the citizens of } \\
\text { Ukraine. } 5 . \\
\text { European and Euro- } \\
\text { Atlantic integration. }\end{array}$ & $\begin{array}{l}\text { In the first place to put } \\
\text { the development of the } \\
\text { economy and human } \\
\text { capital, which will } \\
\text { provide funding for } \\
\text { other areas, including } \\
\text { law enforcement. In } \\
\text { second place is the } \\
\text { resolution of existing } \\
\text { conflicts, especially } \\
\text { those that are frozen } \\
\text { and worsen the } \\
\text { country's economic } \\
\text { situation. }\end{array}$ \\
\hline
\end{tabular}




\begin{tabular}{|c|c|c|c|c|}
\hline \multirow{2}{*}{$\begin{array}{c}\mathrm{N} \\
\mathrm{s} / \mathrm{n}\end{array}$} & \multicolumn{3}{|c|}{ The National Security Strategy of Ukraine was adopted in } & \multirow{2}{*}{$\begin{array}{l}\text { Proposals to improve } \\
\text { Ukraine's national } \\
\text { security strategies }\end{array}$} \\
\hline & $2007[1]$ & $2015[2]$ & $2020[3]$ & \\
\hline & $\begin{array}{l}\text { Improving the } \\
\text { efficiency of public } \\
\text { administration and } \\
\text { local self- } \\
\text { government. } 3 \text {. } \\
\text { Ensuring an } \\
\text { acceptable level of } \\
\text { economic security, } \\
\text { which is impossible } \\
\text { without the } \\
\text { implementation of } \\
\text { structural adjustment } \\
\text { and increasing the } \\
\text { competitiveness of } \\
\text { the national } \\
\text { economy. } 4 \text {. } \\
\text { Ensuring the } \\
\text { country's energy } \\
\text { security, primarily } \\
\text { by radically } \\
\text { improving the } \\
\text { efficiency of fuel } \\
\text { and energy } \\
\text { resources. } 5 \text {. } \\
\text { Achieving high } \\
\text { social standards, } \\
\text { solving urgent } \\
\text { demographic } \\
\text { problems on this } \\
\text { basis. } 6 . \text { Creating } \\
\text { safe living } \\
\text { conditions for the } \\
\text { population. } 7 . \\
\text { Reforming security } \\
\text { sector institutions - } \\
\text { the Armed Forces of } \\
\text { Ukraine, other } \\
\text { military formations } \\
\text { and law enforcement } \\
\text { agencies in order to } \\
\text { ensure their } \\
\text { readiness to perform } \\
\text { state defense tasks, } \\
\text { increase the } \\
\text { andivil rights and }\end{array}$ & $\begin{array}{l}\text { new quality of } \\
\text { economic, social and } \\
\text { humanitarian } \\
\text { development, } \\
\text { ensuring Ukraine's } \\
\text { integration into the } \\
\text { European Union and } \\
\text { creating conditions } \\
\text { for joining NATO. }\end{array}$ & & \\
\hline
\end{tabular}




\begin{tabular}{|c|c|c|c|c|}
\hline \multirow{2}{*}{$\begin{array}{c}\mathrm{N} \\
\mathrm{s} / \mathrm{n}\end{array}$} & \multicolumn{3}{|c|}{ The National Security Strategy of Ukraine was adopted in } & \multirow{2}{*}{$\begin{array}{l}\text { Proposals to improve } \\
\text { Ukraine's national } \\
\text { security strategies }\end{array}$} \\
\hline & $2007[1]$ & $2015[2]$ & $2020[3]$ & \\
\hline & $\begin{array}{l}\text { freedoms, national } \\
\text { security, fight } \\
\text { against corruption } \\
\text { and crime, especially } \\
\text { in its organized } \\
\text { forms. 8. Accelerate } \\
\text { the implementation } \\
\text { of judicial reform in } \\
\text { the direction of } \\
\text { establishing a system } \\
\text { of the judiciary and } \\
\text { the judiciary in } \\
\text { Ukraine, which will } \\
\text { operate on the basis } \\
\text { of the rule of law in } \\
\text { accordance with } \\
\text { European standards } \\
\text { and guarantee the } \\
\text { right of a person to a } \\
\text { fair trial. 9. } \\
\text { Development of a } \\
\text { system of } \\
\text { democratic civilian } \\
\text { control over the } \\
\text { military organization } \\
\text { and law enforcement } \\
\text { agencies of the state. }\end{array}$ & & & \\
\hline 3. & \multicolumn{4}{|c|}{ Threats } \\
\hline & Undefined & $\begin{array}{l}\text { 1. Aggressive } \\
\text { actions of Russia, } \\
\text { carried out to deplete } \\
\text { the Ukrainian } \\
\text { economy and } \\
\text { undermine socio- } \\
\text { political stability in } \\
\text { order to destroy the } \\
\text { state of Ukraine and } \\
\text { capture its territory. } \\
\text { 2. Inefficiency of the } \\
\text { national security and } \\
\text { defense system of } \\
\text { Ukraine. } 3 \text {. } \\
\text { Corruption and } \\
\text { inefficient system of } \\
\text { public } \\
\text { administration. } 4 \text {. } \\
\text { Economic crisis, }\end{array}$ & $\begin{array}{l}\text { 1. Destruction of the } \\
\text { ecosystem and } \\
\text { biocenosis. } \\
2 . \text { Inequality is } \\
\text { growing, other } \\
\text { fundamental } \\
\text { imbalances of world } \\
\text { development persist. } \\
\text { 3. Rapid } \\
\text { technological } \\
\text { changes, especially } \\
\text { in energy and } \\
\text { biotechnology, } \\
\text { developments in the } \\
\text { field of artificial } \\
\text { intelligence, etc. } \\
\text { radically transform } \\
\text { the economy and } \\
\text { society as a whole. }\end{array}$ & $\begin{array}{l}\text { In the first place to put } \\
\text { the need to reform } \\
\text { outdated systems and } \\
\text { bring them to modern- } \\
\text { global, including } \\
\text { updating the outdated } \\
\text { regulatory framework } \\
\text { of the country. In } \\
\text { second place are } \\
\text { economic threats, the } \\
\text { development of } \\
\text { international trade. In } \\
\text { third place is the } \\
\text { country's cybersecurity } \\
\text { and information space. }\end{array}$ \\
\hline
\end{tabular}




\begin{tabular}{|c|c|c|c|c|}
\hline \multirow{2}{*}{$\begin{array}{l}\mathrm{N} \\
\mathrm{s} / \mathrm{n}\end{array}$} & \multicolumn{3}{|c|}{ The National Security Strategy of Ukraine was adopted in } & \multirow{2}{*}{$\begin{array}{l}\text { Proposals to improve } \\
\text { Ukraine's national } \\
\text { security strategies }\end{array}$} \\
\hline & $2007[1]$ & 2015 [2] & 2020 [3] & \\
\hline & & $\begin{array}{l}\text { depletion of } \\
\text { financial resources } \\
\text { of the state, lower } \\
\text { living standards. } 5 \text {. } \\
\text { Threats to energy } \\
\text { security. } 6 \text {. Threats } \\
\text { to information } \\
\text { security. } 7 \text {. Threats } \\
\text { to cybersecurity and } \\
\text { security of } \\
\text { information } \\
\text { resources. } 8 \text {. Critical } \\
\text { infrastructure } \\
\text { security threats. } 9 \text {. } \\
\text { Threats to } \\
\text { environmental } \\
\text { safety. }\end{array}$ & $\begin{array}{l}\text { 4. The modern } \\
\text { model of } \\
\text { globalization has } \\
\text { enabled the spread of } \\
\text { international } \\
\text { terrorism and } \\
\text { international crime. } \\
\text { 5. Spread of } \\
\text { coronavirus disease } \\
\text { (COVID-19). } \\
\text { 6. A new global } \\
\text { financial and } \\
\text { economic crisis due } \\
\text { to the pandemic. } \\
\text { 7. The competition } \\
\text { for world leadership } \\
\text { between the United } \\
\text { States of America } \\
\text { and the People's } \\
\text { Republic of China is } \\
\text { intensifying. } \\
\text { 8. The challenges to } \\
\text { transatlantic and } \\
\text { European unity are } \\
\text { growing, which may } \\
\text { lead to an escalation } \\
\text { of existing and new } \\
\text { conflicts. } \\
9 . \text { To strengthen its } \\
\text { position in Europe, } \\
\text { the Russian } \\
\text { Federation uses } \\
\text { energy and } \\
\text { information } \\
\text { "weapons". } \\
\text { 10. To restore its } \\
\text { influence in Ukraine, } \\
\text { the Russian } \\
\text { Federation continues } \\
\text { the hybrid war. } \\
\text { 11. Special services } \\
\text { of foreign states, } \\
\text { first of all of the } \\
\text { Russian Federation, } \\
\text { continue } \\
\text { reconnaissance and }\end{array}$ & \\
\hline
\end{tabular}




\begin{tabular}{|c|c|c|c|c|}
\hline \multirow{2}{*}{$\begin{array}{l}\mathrm{N} \\
\mathrm{s} / \mathrm{n}\end{array}$} & \multicolumn{3}{|c|}{ The National Security Strategy of Ukraine was adopted in } & \multirow{2}{*}{$\begin{array}{l}\text { Proposals to improve } \\
\text { Ukraine's national } \\
\text { security strategies }\end{array}$} \\
\hline & $2007[1]$ & $2015[2]$ & $2020[3]$ & \\
\hline & & & $\begin{array}{l}\text { subversive activity } \\
\text { against Ukraine } \\
\text { 12. Destructive } \\
\text { propaganda both } \\
\text { outside and inside } \\
\text { Ukraine. } \\
\text { 13. Low levels of } \\
\text { well-being create } \\
\text { despair and } \\
\text { uncertainty about the } \\
\text { future. } \\
\text { 14. Inconsistency } \\
\text { and incomplete } \\
\text { reforms and } \\
\text { corruption hinder the } \\
\text { recovery of the } \\
\text { Ukrainian economy. } \\
\text { 15. Deteriorating } \\
\text { living environment, } \\
\text { air quality, drinking } \\
\text { water, food . } \\
\text { 16. Reduction of } \\
\text { birth rate, high } \\
\text { mortality rate. } \\
\text { 17. Deteriorating } \\
\text { socio-economic } \\
\text { conditions may lead } \\
\text { to increased } \\
\text { emigration. }\end{array}$ & \\
\hline 4. & \multicolumn{4}{|c|}{ The main directions of the state policy of national security of Ukraine } \\
\hline & $\begin{array}{l}\text { 1. Improving the } \\
\text { national security } \\
\text { management system. } \\
\text { 2. Resource } \\
\text { provision of national } \\
\text { security. } 3 \text {. } \\
\text { Principles and } \\
\text { mechanisms of state } \\
\text { and public control } \\
\text { over the } \\
\text { implementation of } \\
\text { the Strategy. }\end{array}$ & $\begin{array}{l}\text { 1. Restoration of the } \\
\text { territorial integrity of } \\
\text { Ukraine. } \\
\text { 2. Creating an } \\
\text { effective security } \\
\text { and defense sector. } \\
\text { 3. Increasing the } \\
\text { state's defense } \\
\text { capabilities. } \\
\text { 4. Reform and } \\
\text { development of } \\
\text { intelligence, } \\
\text { counterintelligence } \\
\text { and law enforcement } \\
\text { agencies. } \\
\text { 5. Reforming the } \\
\text { public administration }\end{array}$ & $\begin{array}{l}\text { 1. Accelerate } \\
\text { defense and security } \\
\text { reform in accordance } \\
\text { with NATO norms, } \\
\text { principles and } \\
\text { standards. } \\
\text { 2. Violations of the } \\
\text { civil rights of } \\
\text { servicemen and } \\
\text { cases of } \\
\text { discrimination, in } \\
\text { particular on the } \\
\text { grounds of gender, } \\
\text { shall not be } \\
\text { permitted. } \\
\text { 3. Ukraine will } \\
\text { strengthen the }\end{array}$ & $\begin{array}{l}\text { In the first place } \\
\text { Updating the legal } \\
\text { framework for } \\
\text { introducing the terms } \\
\text { social conflict and } \\
\text { ways to identify and } \\
\text { resolve them in } \\
\text { advance. In second } \\
\text { place is the } \\
\text { introduction of a } \\
\text { system of correct } \\
\text { allocation of } \\
\text { resources, prevention } \\
\text { of corruption. In third } \\
\text { place is to improve the } \\
\text { professionalism of } \\
\text { existing staff. }\end{array}$ \\
\hline
\end{tabular}




\begin{tabular}{|c|c|c|c|c|}
\hline \multirow{2}{*}{$\begin{array}{l}\mathrm{N} \\
\mathrm{s} / \mathrm{n}\end{array}$} & \multicolumn{3}{|c|}{ The National Security Strategy of Ukraine was adopted in } & \multirow{2}{*}{$\begin{array}{l}\text { Proposals to improve } \\
\text { Ukraine's national } \\
\text { security strategies }\end{array}$} \\
\hline & $2007[1]$ & $2015[2]$ & $2020[3]$ & \\
\hline & & $\begin{array}{l}\text { system, a new } \\
\text { quality of anti- } \\
\text { corruption policy. } \\
\text { 6. Integration into } \\
\text { the European Union. } \\
\text { 7. A special } \\
\text { partnership with } \\
\text { NATO. } \\
\text { 8. Ensuring national } \\
\text { security in the } \\
\text { foreign policy sphere } \\
\text { 9. Ensuring } \\
\text { economic security } \\
\text { 10. Ensuring energy } \\
\text { security. } \\
\text { 11. Ensuring } \\
\text { information security. } \\
\text { 12. Ensuring } \\
\text { cybersecurity and } \\
\text { security of } \\
\text { information } \\
\text { resources. } \\
\text { 13. Ensuring the } \\
\text { security of critical } \\
\text { infrastructure. } \\
\text { 14. Ensuring } \\
\text { environmental } \\
\text { safety. }\end{array}$ & $\begin{array}{l}\text { combat potential of } \\
\text { the Armed Forces of } \\
\text { Ukraine and other } \\
\text { bodies of the defense } \\
\text { forces. } \\
\text { 4. The defense- } \\
\text { industrial complex } \\
\text { will meet the needs } \\
\text { of the Armed Forces } \\
\text { of Ukraine. } \\
\text { 5. The state will help } \\
\text { strengthen the export } \\
\text { potential of the } \\
\text { defense industry. } \\
\text { 6. The development } \\
\text { of the security and } \\
\text { defense sector is } \\
\text { necessary for the } \\
\text { systematic protection } \\
\text { of Ukraine from } \\
\text { threats to national } \\
\text { security. }\end{array}$ & \\
\hline
\end{tabular}

Source: author's development based on [1-3]

Thus, Ukraine has now identified a priority for human development in the context of state security (see the National Security Strategy of Ukraine as of 2020). This is intended to finally strengthen compliance with the provisions in Art. 3 of the Constitution of Ukraine: "The human being, his or her life and health, honour and dignity, inviolability and security are recognised in Ukraine as the highest social value. Human rights and freedoms and their guarantees determine the essence and orientation of the activity of the State. The State is answerable to the individual for its activity. To affirm and ensure human rights and freedoms is the main duty of the State" [4]. In continuation we note that the state is accountable to citizens for its activities and undertakes to resolve social conflicts related to the activities of the state. However, no significant changes in improving the effectiveness of the organizational and legal mechanism of public management of social 
conflicts in Ukraine have been observed so far. In our opinion, the main reason for that is the insufficient use of scientific principles of public administration intended for the creation of mechanisms of state influence in order to resolve social conflicts. Among these principles we can emphasize systematization, preservation of institutional memory, effectiveness, anthropocentrism (or social orientation) etc. They are designed to ensure the proper formation and implementation of mechanisms of public administration which provide for the purposeful influence of the subjects on the object in order to ensure its development by performing basic functions of public administration using a number of methods of influence.

Conclusion of the research. Within the framework of this study, it is proposed to amend the National Security Strategy of Ukraine (2020) in the direction of identifying such types of threats as internal conflicts, including social conflicts. At present they have become the catalyst for socio-political conflicts in Eastern Ukraine, which has led to a crisis of power in the temporarily occupied territories. As a result, the existing unresolved social conflicts lead to lower living standards, intensified migration processes, reduced economic well-being, further misallocation of resources, which reduces the country's economic potential with citizens' dissatisfaction with authorities and distrust. In this context, it is important to study the state of the organizational and legal mechanism of public management of social conflicts in the United Kingdom, the United States and other countries, given the integration aspirations of Ukraine. In fact, it is advisable to analyse

their national security strategy as one of the most important areas of state development. Our further scientific investigations will be devoted to these questions.

\section{References}

1. Ukraine. The President of Ukraine. Strategy of Nathional Security of Ukraine. N.p., 12 Feb. 2007 Web. 13 July 2021 <https://www.president.gov.ua/documents/1052007-5496>.

2. Ukraine. The President of Ukraine. Strategy of Nathional Security of Ukraine. N.p., 6 May 2015 Web. 13 July 2021 <https://www.president.gov.ua/documents/2872015-19070>.

3. Ukraine. The President of Ukraine. Strategy of Nathional Security of Ukraine. N.p., 14 Sept. 2015 Web. 13 July 2021 <https://www.president.gov.ua/documents/3922020-35037>.

4. Ukraine. The Verkhovna Rada of Ukraine. Constitution of Ukraine. Web. 13 July 2021 $<$ https://zakon.rada.gov.ua/laws/show/254к/96-вр>. 